\title{
Effect of integrated forage rotation and manure management on yield, nutrient balance and soil organic matter
}

\author{
Cesare Tomasoni, ${ }^{1}$ Lamberto Borrelli, ${ }^{1}$ Enrico Ceotto² \\ 'CRA-FLC, Centro di Ricerca per le Produzioni Foraggere e Lattiero-casearie, Lodi; \\ ${ }^{2}$ CRA-CIN, Centro di Ricerca per le Colture Industriali, Bologna, Italy
}

\begin{abstract}
This paper reports results from a field experiment established in 1995 and still on going. It is located in Lodi, in the irrigated lowlands of Lombardy, Northern Italy. The experiment compares two rotations: the annual double cropping system, Italian ryegrass + silage maize (R1); and the 6-year rotation, in which three years of double crop Italian ryegrass + silage maize are followed by three years of alfalfa harvested for hay (R6). Each rotation have received two types of dairy manure: i) farmyard manure (FYM); ii) semi-liquid manure (SLM). The intent was to apply to each unit land area the excreta produced by the number of adult dairy cows sustained, in terms of net energy, by the forage produced in each rotation, corresponding to about 6 adult cows ha-1 for R1 and 4 adult cows ha- ${ }^{-1}$ for R6. Manure was applied with (N1) or without (N0) an extra supply of mineral nitrogen (N) in the form of urea. The objectives of this study were: i) to assess whether the recycling of two types of manure in two forage rotation systems can sustain crop yields in the medium and long term without additional $\mathrm{N}$ fertilization; ii) to evaluate the nutrient balance of these integrated forage rotations and manure management systems; iii) to compare the effects of farmyard manure and semi-liquid manure on soil organic matter. The application of FYM, compared to SLM, increased yield of silage maize by $19 \%$ and alfalfa by $23 \%$, while Italian ryegrass was not influenced by the manure treatment. Yet, silage maize produced $6 \%$ more in rotation $\mathrm{R} 6$ compared to rotation $\mathrm{R} 1$. The mineral nitrogen fertilization increased yield of Italian ryegrass by $11 \%$ and of silage maize by $10 \%$. Alfalfa, not directly fertilized with mineral nitrogen, was not influenced by the nitrogen applied to the other crops in rotation. The
\end{abstract}

Correspondence: Dr. Cesare Tomasoni, Centro di Ricerca per le Produzioni Foraggere e Lattiero-casearie, viale Piacenza 29, 26900 Lodi, Italy.

Tel. +39.0371.404733 - Fax: +39.0371.31853. E-mail: cesare.tomasoni@entecra.it

Key words: dairy farming, forage rotations, farmyard and semi-liquid manure, soil fertility.

Received for publication: 8 October 2010.

Accepted for publication: 15 January 2011.

(C) Copyright C. Tomasoni et al., 2011

Licensee PAGEPress, Italy

Italian Journal of Agronomy 2011; 6:e10

doi:10.4081/ija.2011.e10

This article is distributed under the terms of the Creative Commons Attribution Noncommercial License (by-nc 3.0) which permits any noncommercial use, distribution, and reproduction in any medium, provided the original author(s) and source are credited. application of FYM, compared to SLM, increased soil organic matter (SOM) by $+37 \%$ for the rotation $\mathrm{R} 1$, and by $+20 \%$ for the rotation $\mathrm{R} 6$. Conversely, no significant difference on SOM was observed between R1 and R6 with the application of SLM. However, the maize stover used for composting FYM was produced by crops not included in the rotations R1 and R6, consequently the increase of soil carbon was counterbalanced by a deprivation of carbon in other land areas.

\section{Introduction}

Intensification of dairy farming systems has occurred in irrigated fertile areas of the Po Valley. The general tendencies of the dairy farms were: i) to maximize the amount of energy produced with forage crops in fertile soils, by extending silage crops and consequently reducing permanent and rotated meadows; ii) to fulfil the protein needs by importing feed concentrates rich in nitrogen; iii) to simplify the management of animal excreta by producing semi-liquid manure instead of the traditional farmyard manure. Indeed, the application of semi-liquid manure might diminish the benefits of manure application on soil organic matter and soil fertility. Overall, these tendencies caused a drastic reduction of permanent and rotational meadows, which represented the main forage resource until the 1960 's and have decreased by about $50 \%$ in land area in the subsequent two decades (Giardini and Ziliotto, 1988). All intensive livestock systems cause serious problems of manure management. For the purpose of feeding animals, huge amounts of plant products harvested elsewhere are concentrated on small areas. The return of mineral nutrients to the original areas is energy intensive as well as expensive, because animal excreta are characterized by high water content (Begon et al., 1996). A possible way for alleviating the negative effects of intensive forage systems is the reintegration of meadows, notably legume species. The inclusion of alfalfa into crop rotations could reduce the need for chemical fertilisers, promote higher microbiological activity in soils exhausted by continuous cereal cultivation, hence improving the biological fertility, and reduce the losses of nitrogen (Toderi, 1988; Parente, 1996). In fact, when soil nitrate is abundantly available, symbiotic $\mathrm{N}_{2}$ fixation is partially inhibited and alfalfa demonstrates its ability to remove substantial amounts of nitrate from the rooted depths of the soil (Peterson and Russelle, 1991). Long term field experiments are extremely useful in understanding soil processes subject to change over decades, like C dynamics and soil fertility itself (Richter et al., 2007). In particular, poliennal multi-crop experiments are valuable source of information because they provide data in which the unknown effects of previous treatments are minimized (Johnston, 1997).

The objectives of this study were: i) to assess whether the recycling of two types of manure in two forage rotation systems can sustain crop yields in the medium and long term without additional $\mathrm{N}$ 
fertilization; ii) to evaluate the nutrient balance of these integrated forage rotations and manure management systems; iii) to compare the effects of farmyard manure and semi-liquid manure on soil organic matter.

\section{Materials and Methods}

The field experiment here described was established in 1995, and is still on going at the experimental station of CRA-FLC, Centro di Ricerca per le Produzioni Foraggere e Lattiero Casearie, located in Lodi, in the irrigated lowlands of Lombardy, Northern Italy (Lat. $45^{\circ} 19^{\prime} \mathrm{N}$, Long. $9^{\circ} 28^{\prime} \mathrm{E}, 80 \mathrm{~m}$ a.s.l.). The soil is a sandy-loam, mixed, mesic, Typic Haplustalf. In the arable layer $0-30 \mathrm{~cm}$ the main soil characteristics are: sand $65 \%$, silt $22 \%$ and clay $13 \%$; the $\mathrm{pH} 6.2$; the organic carbon $10.6 \mathrm{mg} \mathrm{g}^{-1}$; the total nitrogen (N) $1.46 \mathrm{mg} \mathrm{g}^{-1}$; the available $\mathrm{P}_{2} \mathrm{O}_{5} 41 \mathrm{ppm}$; the exchangeable $\mathrm{K}_{2} \mathrm{O} 41 \mathrm{ppm}$. The climate is temperate subcontinental, the average annual rainfall is about 800 $\mathrm{mm}$, well distributed along the year, and the average annual daily temperature is $12.5^{\circ} \mathrm{C}$ with a minimum of $1.1^{\circ} \mathrm{C}$ in January and a maximum of $22.9^{\circ} \mathrm{C}$ in July (Onofrii et al., 1993b).

The experiment compares two rotations: the annual double cropping system, Italian ryegrass (Lolium multiflorum Lam.) + silage maize (Zea Mays L.) (R1); and the 6-year rotation, in which three years of double crop Italian ryegrass + silage maize are followed by three years of alfalfa (Medicago sativa L.), harvested for hay (R6). Italian ryegrass was sown in middle October to late November and harvested in the first decade of May, silage maize was sown from the end of May to beginning of June and harvested in the middle of September. Alfalfa was sown from the end of March to beginning of April, and was cut 3-4 times per year, for three years. Each rotation received dairy manure in the form of semi liquid manure (SLM), or farmyard manure (FYM) derived from composting cattle excreta with added maize stover. The intent was to apply to each unit land area the excreta produced by the number of adult dairy cows sustained, in terms of energy, by the forage produced by each crop rotation. The assumptions made in estimating the amounts of manure to be applied are: i) Onofrii et al. (1993a), on the basis of a previous rotation experiment, established in Lodi in 1985, calculated that the double crop rotation italian ryegrass+silage maize (R1) produced about 22,000 milk feed unit ha ${ }^{-1}$ year $^{-1}$, and the 6 year rotation italian ryegrass+silage maize (three years) - meadow (three years) (R6) produced about 15,000 milk feed unit ha ${ }^{-1}$ year-1; ii) these authors, assuming a forage loss of $15 \%$ and an annual need of 3000 milk feed unit for an adult dairy cow, estimated that 6 and 4 adult cows could be sustained, respectively, by $\mathrm{R} 1$ and $\mathrm{R} 6$; iii) assuming that each adult cow produces annually about $11 \mathrm{t}$ of FYM and $16.6 \mathrm{~m}^{3}$ of SLM (Bonazzi, 1993), $66 \mathrm{t} \mathrm{ha}^{-1}$ of FYM and $100 \mathrm{~m}^{3} \mathrm{ha}^{-1}$ of SLM were applied annually to rotation R1, while $44 \mathrm{t} \mathrm{ha}^{-1}$ of FYM and $66 \mathrm{~m}^{3} \mathrm{ha}^{-1}$ of SLM were applied annually to rotation R6. Both FYM and SLM were applied on soil surface immediately before soil plowing at $0.3 \mathrm{~m}$ depth. FYM was distributed manually to the plots, while SLM was applied mechanically, using a plot-scale slurry tank of $1 \mathrm{~m}^{3}$ capacity. Both FYM and SLM were sampled at every field distribution to analyse their N, phosphorus (P) and potassium (K) content. Standard analytical methods for the determination of the nutrient content of manure were used in agreement with Cottenie (1979).

Moreover, each manure treatment was applied with or without an additional supply of mineral $\mathrm{N}$ in the form of urea (N1, was $75 \mathrm{~kg} \mathrm{~N}$ $\mathrm{ha}^{-1}$ for Italian ryegrass, $150 \mathrm{~kg} \mathrm{ha}^{-1} \mathrm{~N}$ for maize and $0 \mathrm{~kg} \mathrm{~N} \mathrm{ha}^{-1}$ for alfalfa; N0 was $0 \mathrm{~kg} \mathrm{~N} \mathrm{ha}^{-1}$ for all crops). The mineral nitrogen fertilization was applied during stem elongation of both Italian ryegrass (second decade of March) and maize (beginning of June). Mineral phosphorus and potassium fertilizers were not applied because it was assumed that manure application amply compensates the crops uptake of these nutrients. The experimental design was a strip-splitsplit-plot, with three replicates. Owing to logistic reasons manure treatments were placed in the main plots, crop rotations in the subplots and the mineral nitrogen supply in the sub-sub-plots. Each phase of the rotations was present every year. This implies that in case of alfalfa, the first, second and third year of the crop duration were represented every year, thus the average annual yield entails the productivity of the three subsequent phases of the meadow. In case of both silage maize and Italian ryegrass, the average annual yield entails the productivity of the first, second and third year after alfalfa. Therefore, one single plot was established for the annual rotation $\mathrm{R} 1$, and six plots for the 6 -year rotation R6. The size of each elementary plot was $84 \mathrm{~m}^{2}$. Each combination was replicated in three blocks.

Sprinkler irrigation supplied maize with (65) $\mathrm{mm} 3$ to 4 times per year. Alfalfa was not irrigated, following the common practice in the area. Weeds were controlled chemically on maize and alfalfa. An overview of the management practices applied in the present field experiment is reported in Table 1.

\section{Forage analysis}

For each individual plot dry matter yield and $\mathrm{N}, \mathrm{P}_{2} \mathrm{O}_{5}$ and $\mathrm{K}_{2} \mathrm{O}$ of harvested biomass were determined. A sample of the forage produced by each plot was oven dried at $60^{\circ} \mathrm{C}$ to determine the dry matter content of the harvested biomass. Dried forage samples were milled and sieved for chemical analysis. The sieved samples were analyzed for crude proteins $(\mathrm{CP})(\mathrm{N} \times 6.25)$ using the Kjeldahl method (Pierce and

Table 1. Crop management practices applied on the experiment.

\begin{tabular}{|c|c|c|c|c|c|}
\hline Rotation & n Crop & Manure & $\mathrm{Mg} \mathrm{ha}^{-1}$ & Tillage & $\begin{array}{l}\text { Industrial } \\
\text { nitrogen } \\
\left(\mathrm{kg} \mathrm{ha}^{-1}\right)\end{array}$ \\
\hline \multirow[t]{2}{*}{$\mathrm{R} 1$} & $\begin{array}{l}\text { Italian } \\
\text { ryegrass }\end{array}$ & FYM & 33 & $\begin{array}{l}\text { Plough+rotary- } \\
\text { cultivator }\end{array}$ & $\begin{array}{l}\mathrm{N} 0=0 \\
\mathrm{Nl}=75\end{array}$ \\
\hline & Silage maize & FYM & 33 & $\begin{array}{l}\text { Plough+rotary- } \\
\text { cultivator }\end{array}$ & $\begin{array}{l}\mathrm{N} 0=0 \\
\mathrm{~N} 1=150\end{array}$ \\
\hline \multirow[t]{6}{*}{$\mathrm{R} 6$} & $\begin{array}{c}\text { Italian ryegrass } \\
\text { (3 years) }\end{array}$ & s FYM & 44 & $\begin{array}{l}\text { Plough+rotary- } \\
\text { cultivator }\end{array}$ & $\begin{array}{l}\mathrm{N} 0=0 \\
\mathrm{~N} 1=75\end{array}$ \\
\hline & $\begin{array}{l}\text { Silage maize } \\
\text { (3 years) } \\
\mathrm{Nl}=150\end{array}$ & FYM & 33 & $\begin{array}{l}\text { Plough+rotary- } \\
\text { cultivator }\end{array}$ & $\mathrm{N} 0=0$ \\
\hline & Lucerne: & FYM & & & \\
\hline & - 1st year & & 33 & $\begin{array}{l}\text { Plough+rotary- } \\
\text { cultivator }\end{array}$ & $\begin{array}{l}\mathrm{N} 0=0 \\
\mathrm{~N} 1=0\end{array}$ \\
\hline & $-2^{\text {nd }}$ and $3^{\text {rd }}$ & rd year & 0 & No till & $\mathrm{N} 0=0$ \\
\hline & & & & & $\mathrm{N} 1=0$ \\
\hline \multirow[t]{2}{*}{$\mathrm{R} 1$} & Italian ryegrass & s SLM & 50 & $\begin{array}{l}\text { Plough+rotary- } \\
\text { cultivator }\end{array}$ & $\begin{array}{l}\mathrm{N} 0=0 \\
\mathrm{~N} 1=75\end{array}$ \\
\hline & Silage maize & SLM & 50 & $\begin{array}{l}\text { Plough+rotary- } \\
\text { cultivator }\end{array}$ & $\begin{array}{l}\mathrm{N} 0=0 \\
\mathrm{~N} 1=150\end{array}$ \\
\hline \multirow[t]{5}{*}{$\mathrm{R} 6$} & $\begin{array}{c}\text { Italian ryegrass } \\
\text { (3 years) }\end{array}$ & s SLM & 65 & $\begin{array}{l}\text { Plough+rotary- } \\
\text { cultivator }\end{array}$ & $\begin{array}{l}\mathrm{N} 0=0 \\
\mathrm{~N} 1=75\end{array}$ \\
\hline & $\begin{array}{l}\text { Silage maize } \\
\text { (3 years) }\end{array}$ & SLM & 50 & $\begin{array}{l}\text { Plough+rotary- } \\
\text { cultivator }\end{array}$ & $\begin{array}{l}\mathrm{N} 0=0 \\
\mathrm{~N} 1=150\end{array}$ \\
\hline & Lucerne & SLM & & & \\
\hline & $-1^{\text {st }}$ year & & 50 & $\begin{array}{l}\text { Plough+rotary- } \\
\text { cultivator }\end{array}$ & $\begin{array}{l}\mathrm{N} 0=0 \\
\mathrm{~N} 1=0\end{array}$ \\
\hline & \multicolumn{2}{|c|}{$-2^{\text {nd }}$ and $3^{\text {rd }}$ year } & 0 & No till & $\begin{array}{l}\mathrm{N} 0=0 \\
\mathrm{~N} 1=0\end{array}$ \\
\hline
\end{tabular}

R1, double crop rotation italian ryegrass+silage maize; R6, 6 year rotation italian ryegrass+silage maize; FYM, farmyard manure; SLM, semi-liquid manure; N0, manure without extra supply of mineral nitrogen; N1, manure with extra supply of mineral nitrogen. 
Table 2. Average dry matter, total nitrogen, phosphorus, potassium contents and their variability of farmyard manure and semi-liquid manure applied in the experiment.

\begin{tabular}{|c|c|c|c|c|c|c|c|c|}
\hline & \multicolumn{4}{|c|}{ Mean values } & \multicolumn{4}{|c|}{ Coefficient of variation } \\
\hline & Dry matter \% & Total N \% & $\mathbf{P}_{2} \mathbf{O}_{5} \%$ & $\mathrm{~K}_{2} \mathrm{O} \%$ & Dry matter \% & Total N \% & $\mathrm{P}_{2} \mathrm{O}_{5} \%$ & $\mathrm{~K}_{2} \mathrm{O} \%$ \\
\hline FYM & 28.1 & 0.66 & 0.48 & 0.84 & 23 & 38 & 60 & 48 \\
\hline SLM & 9.2 & 0.25 & 0.18 & 0.36 & 17 & 28 & 22 & 31 \\
\hline
\end{tabular}

$\mathrm{N}$, nitrogen; $\mathrm{P}_{2} \mathrm{O}_{5}$, phosphorus; $\mathrm{K} 2 \mathrm{O}$, potassium; FYM, farmyard manure; $\mathrm{SLM}$, semi-liquid manure.

Haenisch, 1947). The acid detergent fiber (ADF) and neutral detergent fiber (NDF) fractions were determined using the procedures of Van Soest (1973). The milk feed units (MFU) of the forages were calculated by using the following expression $\mathrm{MFU}=[1.044-(0.0123 *$ \%ADF) ]/0.786, according to Chase (1981).

\section{Soil sampling and analysis}

Soil samples were collected on all plots on September 2006, after the harvest of silage maize. They summarizes the cumulative effect of eleven years of continuous rotation and fertilization treatments to the soil. Three independent soil cores were collected on each plot for the soil layer 0-0.3 m which correspond to the depth of ploughing. Soil cores were collected using a soil sampler drill, model Eijkelkamp, 4 $\mathrm{cm}$ diameter. The three soil cores of each plot were combined and sieved to form the sample of the plot. The sieved soil was used to determine the soil organic matter through chromic acid digestion, according to the Walkley-Black method and total $\mathrm{N}$ using the Kjeldahl method, according to Page et al. (1982).

\section{Statistical analysis}

Data reported in this paper refer to the years 2006, 2007 and 2008. The statistical analysis was performed using the GLM procedure of the SAS systems (SAS, 1990). For the variables dry matter yield, MFU and $\mathrm{CP}$, combined analyses were performed for the three years, because constant fertilization treatments were applied annually and no interactions between treatments and years arose. According to Grignani et al. (2007) crop rotations, manure, mineral N fertilization, block, and the interaction between rotation and fertilization treatments were considered as fixed factors, and the between-year variability was considered to be part of the error. A separate analysis was performed for the variable soil organic matter. As previously indicated, data reported refers to soil sampling of the year 2006, hence, no interactions with the years were evaluated.

\section{Results and discussion}

\section{Nutrients applied with manure}

In Table 2 are reported the average composition of FYM and SLM applied in the experiment and their variability. In Table 3 are reported the average annual amounts of nutrients (N, P, K) applied annually to rotations R1 and R6 with the two types of manure. Despite of the intent to apply equivalent amounts of animal excreta with different types of manure, the application of FYM have resulted in higher supply of nutrients compared to SLM. On average, the application of SLM provided only $57 \%$ of $\mathrm{N}$ and $\mathrm{P}$ and $65 \%$ of $\mathrm{K}$ compared to FYM. There are three circumstances that might have contributed in determining these differences: i) the addition of maize stover to the animal excreta in composting FYM implies that, beside to carbon, more N, P and $\mathrm{K}$ are embedded in the product; ii) different extent of nitrogen gaseous losses might have occurred during preparation and storage of FYM
Table 3. Average amounts of nutrients $\left(\mathrm{kg} \mathrm{ha}^{-1}\right.$ year $\left.^{-1}\right)$ applied annually to rotations $\mathrm{R} 1$ and $\mathrm{R} 6$ with organic fertilizers, differences between farmyard manure and semi-liquid manure, estimated contribution of maize stover and unaccounted quantities.

$\begin{array}{lccc}\text { Rotation } & \mathrm{N} & \mathrm{P}_{2} \mathrm{O}_{5} & \mathrm{~K}_{2} \mathrm{O} \\ \text { R1 FYM } & & & \\ \text { SLM } & 436 & 316 & 554 \\ \text { Difference FYM-SLM } & 250 & 180 & 360 \\ \text { Estimated stover contribution } & 186 & 136 & 194 \\ \text { Unaccounted } & 81.5 & 11.4 & 143.7 \\ \text { R6 } & 104.5 & 124.6 & 50.3 \\ \text { FYM } & & & \\ \text { SLM } & 290 & 211 & 370 \\ \text { Difference FYM-SLM } & 165 & 119 & 237 \\ \text { Estimated stover contribution } & 125 & 92 & 133 \\ \text { Unaccounted } & 54.3 & 7.6 & 95.8 \\ \end{array}$

$\mathrm{N}$, nitrogen; $\mathrm{P}_{2} \mathrm{O}_{5}$, phosphorus; $\mathrm{K}_{2} \mathrm{O}$, potassium; $\mathrm{R} 1$, double crop rotation Italian ryegrass+silage maize; $\mathrm{R} 6,6$ year rotation Italian ryegrass+silage maize; FYM, farmyard manure; SLM, semi-liquid manure.

and SLM; iii) the SLM used in the present experiment was likely more diluted than assumed when the experiment was devised. Since FYM is an inherently variable material, it is difficult to quantify precisely the amount of maize stover used for its preparation. However, an attempt to quantify the contribution of maize stover to the nutrient content of FYM is appropriate here. According to Draghetti (1948) about $3-5 \mathrm{~kg}$ of litter per day, equivalent to 1.1 to $1.7 \mathrm{Mg}$ per year, are necessary for one adult cow. This author pointed out that the addition of litter to the excreta, beside to substantial amount of $\mathrm{C}$, implies that several kilograms of $\mathrm{N}, \mathrm{P}$ and $\mathrm{K}$ are also embedded in FYM. Assuming an average of $4 \mathrm{~kg}$ litter $\mathrm{cow}^{-1}$ day $^{-1} \times 365$ days $=1460 \mathrm{~kg}$ of maize stover per cow per year are needed for FYM production. Hence, the 6 and 4 cows sustained by the rotations $\mathrm{R} 1$ and $\mathrm{R} 6$ require respectively about 8760 and $5840 \mathrm{~kg}$ of maize stover per year to be added to the animal excreta. For a well fertilized maize crop, the nutrients concentration of the maize stover dry matter are: N $0.93 \%$, P $0.13 \%$, K $1.64 \%$ and C 45\% (Ceotto, 1999). Thus, for the rotation R1 the nutrient content of maize stover can be estimated as follows: $8760 \mathrm{~kg}$ of stover $\mathrm{x}$ N $0.93 \%=81.5 \mathrm{~kg}$ N; x P 0.13\%=11.4 kg P; x K 1.64\%= $143.7 \mathrm{~kg} \mathrm{~K}$. Yet, for the rotation $\mathrm{R} 6$ the nutrient content of maize stover can be estimated as: $5840 \mathrm{~kg}$ of stover x N 0.93\%=54.3 kg N; x P 0.13\%=7.6 $\mathrm{kg} \mathrm{P}$; $\mathrm{x}$ K $1.64 \%=95.8 \mathrm{~kg} \mathrm{~K}$. These amounts of nutrients can only partially explain the difference between FYM and SLM application. Therefore, it is likely that the dilution of SLM have played a substantial role in determining the observed differences in nutrient supply by the two types of manure.

\section{Dry matter yield}

The results of the analysis of variance and the average dry matter yields of the individual crops for the period 2006-2008 are presented in Table 4. The application of FYM, compared to SLM, increased yield 
Table 4. Analysis of variance and mean values of dry matter yields, crude proteins and milk feed unit for the period 2006-2008.

\begin{tabular}{|c|c|c|c|c|c|c|}
\hline Source & df & $\begin{array}{r}\text { Dry } \\
\text { Italian ryegrass }\end{array}$ & $\begin{array}{r}\text { A } \\
\text { tter yield (Mg } \\
\text { Silage maize }\end{array}$ & $\begin{array}{l}\text { s of vari } \\
\text { Alfalfa }\end{array}$ & $\mathrm{CP}\left(\mathrm{Mg} \mathrm{ha}^{-1}\right)$ & MFU ha-1 \\
\hline Manure & 1 & ns & $*$ & $*$ & $* *$ & $* *$ \\
\hline Rotation & 1 & ns & $*$ & - & $* *$ & $* * *$ \\
\hline Manurexrotation & 1 & ns & ns & - & ns & ns \\
\hline Mineral N & 1 & $*$ & $* *$ & ns & $* * *$ & $* *$ \\
\hline Manurexmineral N & 1 & ns & ns & ns & ns & ns \\
\hline Rotationxmineral N & 1 & ns & ns & - & ns & ns \\
\hline Manurexrotxmin N & 1 & ns & ns & - & ns & ns \\
\hline FYM & means & $6.41^{\mathrm{a}}$ & $19.34^{\mathrm{a}}$ & $13.19^{a}$ & $1.93^{\mathrm{a}}$ & $19,808^{\mathrm{a}}$ \\
\hline SLM & means & $5.86^{\mathrm{a}}$ & $16.30^{\mathrm{b}}$ & $10.71^{\mathrm{b}}$ & $1.57^{\mathrm{b}}$ & $16,840^{\mathrm{b}}$ \\
\hline $\mathrm{R} 1$ & means & $6.07^{\mathrm{a}}$ & $17.28^{b}$ & - & $1.58^{\mathrm{b}}$ & $20,672^{\mathrm{a}}$ \\
\hline $\mathrm{R} 6$ & means & $6.20^{\mathrm{a}}$ & $18.36^{\mathrm{a}}$ & - & $1.93^{\mathrm{a}}$ & $15,976^{\mathrm{b}}$ \\
\hline No & means & $5.81^{\mathrm{b}}$ & $16.97^{\mathrm{b}}$ & $11.89^{\mathrm{a}}$ & $1.60^{\mathrm{b}}$ & $17,575^{b}$ \\
\hline N1 & means & $6.46^{\mathrm{a}}$ & $18.67^{\mathrm{a}}$ & $12.01^{\mathrm{a}}$ & $1.91^{\mathrm{a}}$ & $19,074^{\mathrm{a}}$ \\
\hline
\end{tabular}

CP, crude proteins; MFU, milk feed unit; df, degrees of freedom; N, nitrogen; FYM, farmyard manure; SLM, semi-liquid manure; R1, double crop rotation Italian ryegrass+silage maize; ns, not significantly different; *significant at $\mathrm{P}<0.05 ;{ }^{* *}$ significant at $\mathrm{P}<0.01$; ${ }^{* * *}$ significant at $\mathrm{P}<0.001$. R6, 6 year rotation Italian ryegrass+silage maize; $\mathrm{N} 0$, manure without extra supply of mineral nitrogen; $\mathrm{N1}$, manure with extra supply of mineral nitrogen; a,bmeans sharing common letters are not significantly different for $\mathrm{P} \leq 0.05$ (least significant difference).

of silage maize by $19 \%$ and alfalfa by $23 \%$, while Italian ryegrass was not influenced by the manure treatment. Interestingly, silage maize produced $6 \%$ more in rotation $\mathrm{R} 6$ with respect to rotation $\mathrm{R} 1$. This is attributable to the residual effect of the three years of alfalfa meadow in rotation. Conversely, no effect of the rotation was observed for Italian ryegrass. The mineral $\mathrm{N}$ fertilization increased the average annual yield by $11 \%$ for Italian ryegrass and by $10 \%$ for silage maize. Alfalfa, not directly fertilized with mineral N, was not influenced by the nitrogen applied to the other crops in rotation.

Since SLM was applied to alfalfa just before sowing, our data indicate that the application of SLM should be avoided in the critical phase of the crop establishment. In contrast, but not in contradiction, Ceotto and Spallacci (2006) reported a positive effect on alfalfa productivity for pig slurry applied after cuttings on second, third and fourth year alfalfa, not fertilized on the first year of crop establishment.

\section{Milk feed units and crude protein production}

Milk feed units and crude proteins production are intrinsically dependent on the type of rotation. In fact, compared to R1, the inclusion on the three year alfalfa meadow in the rotation R6 implies that more proteins $(+22 \%)$ and less energy ( $-23 \%$ milk feed unit) are produced per land unit (Table 4). Overall, FYM application, compared to SLM, increased crude protein production by $23 \%$ and milk feed unit by $18 \%$. This is likely due to higher annual nutrients supply, and also to the increment of soil organic matter determined by repeated application of FYM. Furthermore, the application of mineral nitrogen fertilizer (N1), compared to N0, increased crude protein production by $19 \%$ and milk feed unit by $9 \%$. Therefore, our data indicate that the sole application of manure, even at high doses, cannot completely fulfil the nitrogen requirements of the crops, hence a mineral nitrogen supplement is required to achieve the maximum productivity per unit land, both in terms of energy and proteins.

\section{Nutrients balances}

The nutrient balances for $\mathrm{N}, \mathrm{P}_{2} \mathrm{O}_{5}$ and $\mathrm{K}_{2} \mathrm{O}$, calculated as a difference between agronomic inputs of nutrient and removal with harvested forages are reported in Table 5. Our data revealed that the rotation $\mathrm{R} 1$, in combination with FYM lead to high $\mathrm{N}$ and $\mathrm{P}$ surplus, that are
Table 5. Nutrient balances $\left(\mathrm{kg} \mathrm{ha}^{-1}\right.$ year $\left.^{-1}\right)$. Average values for the period $2006-2008 \mathrm{~kg} \mathrm{ha}^{-1}$. Since alfalfa is a nitrogen fixing crop it was considered neutral with respect to nitrogen.

\begin{tabular}{|c|c|c|c|c|c|c|c|c|c|c|}
\hline & & & $\mathbf{N}$ & $\mathrm{P}_{2} \mathrm{O}_{5}$ & $\mathrm{~K}_{2} \mathrm{O}$ & & tilizat & & $\mathbf{N}$ & $\mathrm{P}_{2} \mathrm{O}_{5} \mathrm{~K}_{2} \mathrm{O}$ \\
\hline \multirow[t]{4}{*}{ FYM } & $\mathrm{B} 1$ & No & 273 & 72 & 334 & 436 & 316 & 554 & 163 & $244 \quad 220$ \\
\hline & $\mathrm{R} 1$ & $\mathrm{~N} 1$ & 340 & 78 & 35 & 661 & 316 & 554 & 321 & $238 \quad 197$ \\
\hline & R6 & No & 138 & 55 & 21 & 254 & 211 & 370 & 116 & $\begin{array}{ll}156 & 57\end{array}$ \\
\hline & $\mathrm{R} 6$ & 10 & 110 & 58 & & 367 & 211 & 370 & 189 & $153 \quad 42$ \\
\hline \multirow[t]{4}{*}{ SLM } & $\mathrm{R} 1$ & No & 213 & 60 & 28 & 250 & 180 & 360 & 37 & $120 \quad 80$ \\
\hline & $\mathrm{R} 1$ & $\mathrm{~N} 1$ & 286 & 67 & 31 & 475 & 180 & 360 & 189 & $113 \quad 49$ \\
\hline & R6 & N0 & 116 & 46 & 25 & 143 & 117 & 234 & 26 & $71 \quad-23$ \\
\hline & $\mathrm{R} 6$ & $\mathrm{Nl}$ & 154 & 50 & 282 & 257 & 117 & 234 & 104 & $\begin{array}{ll}67 & -48\end{array}$ \\
\hline
\end{tabular}

$\mathrm{N}$, nitrogen; $\mathrm{P}_{2} \mathrm{O}_{5}$, phosphorus; $\mathrm{K}_{2} \mathrm{O}$, potassium; FYM, farmyard manure; SLM, semi-liquid manure; $\mathrm{R} 1$, double crop rotation Italian ryegrass+silage maize; $\mathrm{R}$ 6, 6 year rotation Italian ryegrass+silage maize; N0, manure without extra supply of mineral nitrogen; $\mathrm{N1}$, manure with extra supply of mineral nitrogen.

likely to determine undesired nutrients losses in the surrounding ecosystems. However, the highest $\mathrm{N}$ surplus value, $321 \mathrm{~kg} \mathrm{ha}^{-1}$ year-1, calculated for the combination R1 with $\mathrm{N} 1$, are not surprising because it falls in the range of 300 to $338 \mathrm{~kg} \mathrm{~N} \mathrm{ha}^{-1}$ year-1 reported for dairy farms in the Po valley (Grignani et al., 2003; Bassanino et al. 2007). Compared to the intensive annual rotation R1, the rotation $\mathrm{R} 6$ is certainly more equilibrated, due to the lower load of animals per unit land, and also to the presence of alfalfa, that provide $\mathrm{N}$ which is fixed locally, instead of being imported from external arable land in the form of feed concentrates.

The rotations $\mathrm{R} 1$ and $\mathrm{R} 6$ in combination with SLM and N0, are associated with little $\mathrm{N}$ surplus. However, the problem of $\mathrm{P}$ imbalance still remains. Hence, our findings confirm the well established principle that either a reduction of the animal raised per unit land area, or an extended distribution of manure is necessary to achieve nutrient balances that are sustainable in the long term. 


\section{Soil organic matter}

The effect of manure application, in combination with the crop rotation, on soil organic matter (SOM) is presented in Figure 1. A statistically significant effect resulted for the interaction manure $\mathrm{x}$ rotation. In fact, the application of FYM, compared to SLM increased SOM of $+37 \%$ for the rotation R1, and of $+20 \%$ for the rotation $\mathrm{R} 6$. Conversely, no significant difference on SOM was observed between R1 and R6 with the application of SLM. Moreover, the SOM content of both rotations R1 and R6 fertilized with SLM, are not statistically different from the SOM content measured in 1995, at the outset of the experiment.

The highest value of SOM, i.e. $2.47 \%$, measured on the intensive treatment R1 combined with FYM, is lower than the value of $2.94 \%$ reported by Lanza and Spallacci (1970) after 18 years of continuous application of $40 \mathrm{Mg}$ of FYM ha ${ }^{-1}$ integrated by mineral $\mathrm{N}$, on a loam soil in Modena (Emilia-Romagna Region, Italy). The two mentioned values of SOM are site specific, because they refers to different combinations of soil and climate, however, considering the slow dynamic of SOM it is possible that soil carbon is still accumulating in the present experiment. While there is compelling evidence that FYM is much more effective than SLM in increasing soil organic matter, a cautionary remark is appropriate here. From the standpoint of carbon (C) cycle it is important to consider that the maize crop providing the stover used to produce FYM was not included in the rotation R1 and R6. This implies that most of the carbon embedded in FYM was imported from land area outside the two forage rotations under study. This might lead to increase the organic matter of the soil at the expenses of other land area that is deprived by its crop residues. Moreover, both rotations R1 and R6 are examples of extreme intensification of forage production, in which all the aboveground biomass produced by the crops is used for feeding animals, while grain crop residues, necessary for composting FYM, need to be imported from external cropland. As previously mentioned, according to Draghetti (1948) about 3-5 kg of litter per day is necessary for one adult cow. Assuming an average of $4 \mathrm{~kg}$ litter $\mathrm{cow}^{-1}$ day $^{-1} \times 365$ days $=1460 \mathrm{~kg}$ of maize stover per cow $^{-1}$ are necessary for composting the FYM of one cow for one year. Hence, the 6 and 4 cows sustained by the rotations $\mathrm{R} 1$ and R6 require respectively about 8760 and $5840 \mathrm{~kg}$ of maize stover year ${ }^{-1}$. Assuming an average carbon content of $45 \%$ for maize stover, and considering the ratio between the atomic weight of $\mathrm{C}$ and molecular weight of $\mathrm{CO}_{2}(12 / 44=0.2728), 8760 \mathrm{~kg}$ of stover x $0.45 \mathrm{C}=$

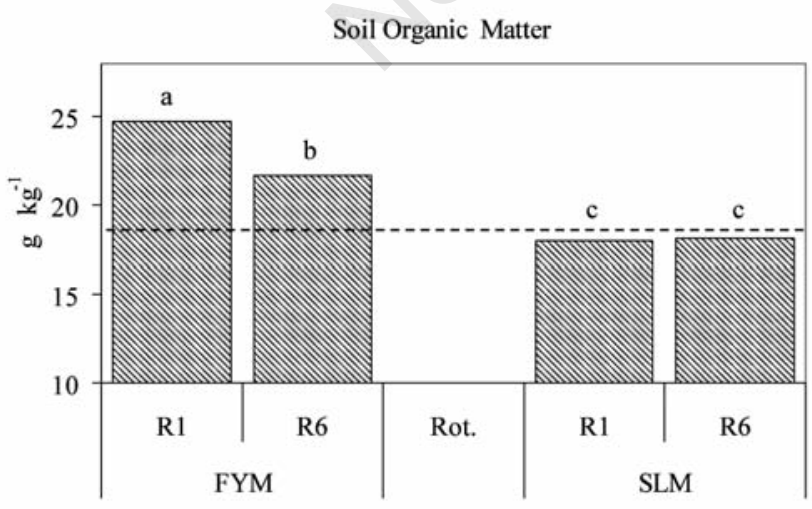

Figure 1. Soil organic matter for the soil layer 0-0.3 m. ANOVA results: Manure $=$ significant at $\mathbf{P}<0.01$ Rotation $=$ significant at $\mathrm{P}<0.05$; Manure $x$ rotation $=$ significant at $\mathrm{P}<0.05$; Means sharing common letters are not significantly different for $\mathrm{P} \leq \mathbf{0 . 0 5}$ (least significant difference). The dashed line indicates the level of organic matter at the outset of the experiment.
$3942 \mathrm{~kg} \mathrm{C} / 0.2728=14450 \mathrm{~kg}$ of $\mathrm{CO}_{2}$ are necessary annually, in form of maize stover for composting the animal excreta of the rotation R1, and $5840 \mathrm{~kg}$ of stover $\mathrm{x} 0.45 \mathrm{C}=2628 \mathrm{~kg} \mathrm{C} / 0.2728=9634 \mathrm{~kg}$ of $\mathrm{CO}_{2}$, have to be used for composting FYM of the rotation R6. Assuming an average maize stover production of $9000 \mathrm{~kg} \mathrm{ha}^{-1}$, it can be estimated that about 0.98 and 0.65 ha, respectively, of external land must provide their crop residues to produce the FYM necessary for 1 ha of the rotation $\mathrm{R} 1$ and $\mathrm{R} 6$ receiving FYM. Yet, assuming that the grain maize is rotated in a three-year rotation, about $3 \times 0.65=2.98$ ha and $3 \times 0.98=2.94$ ha of external land must provide annually their maize stover necessary to enrich the soil $\mathrm{C}$ stock of one ha cultivated with the forage rotations devised in the present experiment.

Our findings are in good agreement with Schlesinger (1999; 2000), who pointed out that no net sink for $\mathrm{C}$ is likely to accompany the use of manure on agricultural land when the boundaries of the system are properly considered. Schlesinger (1999) using data of Missouri (USA), estimated that the entire above-ground plant production on 3.0 ha of land was required to supply the manure to each hectare of manured land. Consequenlty, the author concluded that greater concentrations of SOM in manured fields can be expected to be associated with declining SOM on a proportionally larger area of off-site lands. Our findings, however, refer to a different situation in which intensive forage rotation systems produce heavy load of manure. Under our experimental conditions are maize crop residues, rather than manure, that need to be produced on extra land to prepare the FYM necessary to increase soil carbon storage.

Different conclusions were drawn by Bertora et al. (2009), who pointed out that farmyard manure application is a superior technique with respect to slurry application because the composting allows more carbon to be transformed into stable organic matter. Moreover, Yamulki (2006) indicated that increasing the carbon content of the manure heap with high-C additives, such as straw or maize stover, might provide the opportunity for $\mathrm{N}_{2} \mathrm{O}$ and $\mathrm{CH}_{4}$ emission reduction. Nevertheless, our data suggest that a pitfall is just around the corner: unless farmyard manure is evenly distributed on the whole surface providing the crop residues needed to its preparation, it may result in concentrating $\mathrm{C}$ deprived elsewhere.

\section{Conclusions}

Most of the integrated forage rotations - manure management systems compared in this experiment are quite intensive for their own devise, because of their high number of dairy cows raised per unit land area and the intrinsic dependence on grain crop residues needed for composting animal excreta. Therefore, we believe that grain crops should be included in forage crop rotations to achieve more sustainable land use.

While the cropping systems receiving FYM plus industrial N provided the higher yields, they are associated with nutrient surpluses that appears to be unacceptable in the long term. On the one hand, lower nitrogen input, associated with little cost on productivity, might be an acceptable compromise for diminishing $\mathrm{N}$ load of the farming systems. On the other hand, the extent of $P$ surpluses of the systems under study suggest that, in order to achieve more sustainable agricultural systems the number of animals per unit land should be definitively reduced. In alternative, an effective system of manure transportation and distribution at territorial scale should be implemented. Yet, our findings suggest that a careful distribution of manure would be necessary to ensure that cropland providing crop residues for composting animal excreta will receive a fraction of the FYM produced. Otherwise, FYM application might result in concentrating $\mathrm{C}$ in areas surrounding livestock activities and in $\mathrm{C}$ deprivation elsewhere. 


\section{References}

Bassanino M., Grignani C., Sacco D., Allisiardi E. 2007. Nitrogen balances at the crop and the farm gate scale in livestock farms in Italy. Agr. Ecosyst. Environ. 122:282-294.

Begon M., Harper J.L., Townsend C.R. 1996. The Flux of Matter through Communities. In: Ecology: Individuals, Populations and Communities. Blackwell Science Ltd., Oxford, UK, pp. 744-774.

Bertora C., Zavattaro L., Sacco D., Monaco S., Grignani C. 2009. Soil organic matter dynamics and losses in manured maize-based forage systems. Eur. J. Agron. 30:177-186.

Bonazzi G. 1993. Determinazione delle caratteristiche dei reflui. In: L. Cortellini (ed.) Manuale per la gestione e l'utilizzazione agronomica dei reflui zootecnici. Centro Ricerche Produzioni Animali, Reggio Emilia, Italy, pp. 13-26.

Ceotto E. 1999. Exploring cropping systems of the low Po valley using the system approach. MSc Thesis, Wageningen Agricultural University, The Netherlands.

Ceotto E., Spallacci P. 2006. Pig slurry applications on alfalfa: productivity, solar radiation utilization, $\mathrm{N}$ and $\mathrm{P}$ removal. Field Crops Res. 95:135-155.

Cottenie A. (Ed.) 1979. Workshop on Standardization of Analytical Methods for Manure, Soils, Plant and Water, Ghent, 1978. Luxembourg, CEE Agricultures series EUR 6368 EN, 57 pp.

Chase L.E. 1981. Energy prediction equatons in USA at NY Hydhia Forage Laboratory. Production Agricultural Training School, Ithaca, NY, USA.

Draghetti A. 1948. Principi di Fisiologia dell'Azienda Agraria. Ist. Edit. Agricolo, Bologna, Italy.

Giardini L., Ziliotto U. 1988. Foraggicoltura e ambiente nella pianura padana. In: Il Futuro della Foraggicoltura Prativa nella Pianura Padana. ISCF, Lodi, Italy, pp 245-262.

Grignani C., Sacco D., Bassanino M., Mantovi P. Bonazzi G., Cumino P. 2003. Nutrient management at farm scale. Country report: Italy. Proc. EGF Workshop "Dairy farming systems and environment", Quimper, France, 2003:37-53.

Grignani C., Zavattaro L., Sacco D., Monaco S. 2007. Production, nitrogen and carbon balance of maize-based forage systems. Eur. J. Agron. 26:442-453.

Johnston A.E. 1997. The value of long-term field experiments in agricultural, ecological and environmental research. Adv. Agron.
59:291-233.

Lanza F., Spallacci P. 1970. Influenza della letamazione a lungo termine sulla fertilità del terreno, sul bilancio della sostanza organica e sulle produzioni agrarie. Nota I. Annali Istituto Sperimentale Agronomico I 2:303-332.

Onofrii M., Tomasoni C., Borrelli L., 1993a. Comparison between fodder cropping rotations carried out with or without meadow in the intensive farming systems of the Po valley plain (Italy). pp. 815816 in Proc. XVII Int. Grassland Congr., Palmerston North, New Zealand.

Onofrii M., Tomasoni C., Borrelli L., 1993b. Confronto tra ordinamenti cerealicoli-foraggeri sottoposti a due livelli di input agrotecnico, nella pianura irrigua lombarda. I. Produzioni quanti-qualitativi. Riv. Agron. 3:160-172.

Yamulki S., 2006. Effect of straw addition on nitrous oxide and methan emissions from stored farmyard manures. Agr. Ecosys. Environ. 112:140-145.

Page A.L., Miller R.H., Keeney D.R., 1982. Methods of soil analysis. 2nd ed. Agronomy monograph n. 9, American Society of Agronomy, Madison, WI, USA.

Parente G. 1996. Grassland and land use systems. In: G. Parente, J. Frame and S. Orsi (eds.). pp. 23-34 in Proc. 16th Meet. European Grassland Federation, ERSA, Gorizia, Italy.

Peterson T.A., Russelle M.P. 1991. Alfalfa and the nitrogen cycle in Corn Belt. J. Soil Water Conserv., 46: 229-235.

Pierce W.C., Haenisch E. L. 1947. Quantitative Analysis, 3rd ed. John Wiley \& Sons, New York, NY, USA.

Richter Jr. D.D., Hofmockel M., Callaham M.A. Jr., Powlson D.S., Smith P. 2007. Long-Term soil experiments: Keys to managing Earth's Rapidly Changing Ecosystems. Soil Sci. Soc. Am. J. 71: 266-279.

SAS 1990. User's Guide, version 6, 4th ed. SAS Inst., Inc., Cary, NC, USA.

Schlesinger W.H. 1999. Carbon and Agriculture: Carbon Sequestration in Soils. Science 284:2095.

Schlesinger W.H. 2000. Carbon sequestration in soils: some cautions amidst optimism. Agr. Ecosyst. Environ. 82:121-127.

Toderi G. 1988. Il ruolo del prato sulla fertilità del terreno. In: Il Futuro della Foraggicoltura Prativa nella Pianura Padana. ISCF, Lodi, Italy, pp 225-243.

Van Soest P.J. 1973. Collaborative study of acid detergent fiber and lignin. J. AOAC 56:781-784. 